UDC 579.222.4

LBC 28.4

\title{
SULPHATE-REDUCING MICROORGANISMS: THE STUDY OF PHYLOGENETIC COMMUNITY COMPOSITION, METABOLIC PROPERTIES, A ROLE IN NATURAL AND ANTHROPOGENIC ECOSYSTEMS
}

\author{
Andrey L. Brukhanov \\ Lomonosov Moscow State University, Moscow, Russian Federation
}

Nicolay V. Pimenov

Winogradsky Institute of Microbiology, Research Center of Biotechnology RAS, Moscow, Russian Federation

Tatyana V. Khizniak

Winogradsky Institute of Microbiology, Research Center of Biotechnology RAS, Moscow, Russian Federation

\begin{abstract}
Representatives of sulfate-reducing bacteria are among the oldest microorganisms on Earth and play a key role in the global biogeochemical cycles of carbon and sulfur, especially in marine ecosystems. Using the modern molecular biological methods based on the analysis of genes $16 \mathrm{~S}$ rRNA and dsrAB the heterogeneous phylogenetic composition of different communities of sulfate-reducing bacteria in the water column and sediments of the Barents, Baltic and Black seas was studied. In particular, we have found representatives of the genera Desulfovibrio, Desulfomicrobium, Desulfotomaculum, Desulfococcus, Desulfosarcina, Desulfobacter. For the first time, pure cultures were obtained and the psychrophilic black sea sulfate-reducing bacteria from the water column and bottom sediments of the Black sea were fully characterized. In particular, we described as a new species of Desulfofrigus euxinos, which has a wider range of used donors and electron acceptors than a typical strain.

Key words: sulphate-reducing microorganisms, phylogeny of communities, natural and anthropogenic ecosystems.
\end{abstract}

УДК 579.222 .4

ББК 28.4

\section{СУЛЬФАТРЕДУЦИРУЮЩИЕ МИКРООРГАНИЗМЫ: ИЗУЧЕНИЕ ФИЛОГЕНЕТИЧЕСКОГО СОСТАВА СООБЩЕСТВ, ОСОБЕННОСТЕЙ МЕТАБОЛИЗМА, ВАЖНОЙ РОЛИ В ПРИРОДНЫХ И АНТРОПОГЕННЫХ ЭКОСИСТЕМАХ}

\author{
Андрей Леонидович Брюханов \\ Московский государственный университет им. М.В. Ломоносова, г. Москва, Российская Федерация \\ Николай Викторович Пименов \\ Институт микробиологии им. С.Н. Виноградского ФИЦ «Фундаментальные основы биотехнологии» РАН, \\ г. Москва, Российская Федерация \\ Татьяна Владимировна Хижняк \\ Институт микробиологии им. С.Н. Виноградского ФИЦ «Фундаментальные основы биотехнологии» РАН, \\ г. Москва, Российская Федерация


Аннотация. Представители сульфатредуцирующих бактерий являются одними из древнейших микроорганизмов на Земле и играют ключевую роль в глобальных биогеохимических циклах углерода и серы, особенно в морских экосистемах. С помощью современных молекулярно-биологических методов на основе анализа генов $16 \mathrm{~S}$ рРНК и $d s r A B$ изучается неоднородный филогенетический состав различных сообществ сульфатредуцирующих бактерий в водной толще и донных осадках Баренцева, Балтийского и Черного морей, где, в частности, нами были обнаружены представители родов Desulfovibrio, Desulfomicrobium, Desulfotomaculum, Desulfococcus, Desulfosarcina, Desulfobacter. Были впервые получены чистые культуры и полностью охарактеризована психрофильная черноморская сульфатредуцирующая бактерия из водной толщи и донных осадков Черного моря. В частности, была описана как новый вид Desulfofrigus euxinos, обладающая более широким спектром используемых доноров и акцепторов электронов, чем типовой штамм.

Ключевые слова: сульфатредуцирующие микроорганизмы, филогения сообществ, природные и антропогенные экосистемы.

Сульфатредуцирующие микроорганизмы - филогенетически неоднородная группа бактерий и архей, представители которой способны получать энергию за счет окисления молекулярного водорода или преимущественно низкомолекулярных органических соединений в строго анаэробных условиях, используя сульфат в качестве основного конечного акцептора электронов (диссимиляционная сульфатредукция). Большая часть представителей сульфатредуцирующих бактерий (СРБ), делящихся на пять основных филогенетических подгрупп, относится к филуму Proteobacteria (класс Deltaproteobacteria), а также к филуму Firmicutes (класс Clostridia).

СРБ являются одними из древнейших микроорганизмов на Земле и играют ключевую роль в глобальных биогеохимических циклах серы и углерода, образуя сероводород и осуществляя терминальные стадии минерализации органического углерода. Наиболее распространены и метаболически активны СРБ в донных осадках Мирового океана (часто составляя там 10-30 \% от всех микроорганизмов), встречаются они также в различных водоемах и сточных водах, богатых сульфатами и разлагающимися органическими веществами. В настоящее время с помощью современных молекулярно-биологических методов на основе анализа генов $16 \mathrm{~S}$ $\mathrm{pPHK}$ и $d s r A B$ (кодирующего диссимиляционную (би)сульфитредуктазу) активно изучается неоднородный филогенетический состав различных сообществ СРБ в водной толще и донных осадках Баренцева, Балтийского и Черного морей, где, в частности, нами были обнаружены представители родов Desulfovibrio, Desulfomicrobium, Desulfotomaculum, Desulfococcus, Desulfosarcina, Desulfobacter и др. $[2 ; 3 ; 6]$.
Нами были впервые получены чистые культуры СРБ из водной толщи и донных осадков Черного моря, являющегося одним из крупнейших в мире резервуаров растворенного сероводорода, где анаэробные глубинные воды, насыщенные $\mathrm{H}_{2} \mathrm{~S}$, не смешиваются с верхним, кислородсодержащим водным слоем. В частности, была описана как новый вид Desulfofrigus euxinos и полностью охарактеризована психрофильная черноморская СРБ, выделенная из водной пробы на континентальном шельфе с глубины 30 м и обладающая более широким спектром используемых доноров и акцепторов электронов, чем типовой штамм Desulfofrigus fragile [1].

Важно отметить, что некоторые виды СРБ, в частности, представители рода Desulfovibrio, способны сохранять жизнеспособность в циано-бактериальных матах, активных илах сточных вод, подповерхностной водной толще, прибрежных донных осадках и иных местообитаниях, регулярно подвергающихся воздействию кислорода, обладая эффективными ферментативными системами антиокислительной защиты, а также населяя анаэробные микрониши во взвешенных в воде органических частицах и образуя агрегаты клеток в присутствии $\mathrm{O}_{2}$. Для снижения внутриклеточной концентрации токсичных продуктов неполного восстановления кислорода клетки аэротолерантных СРБ содержат как классические антиокислительные ферменты (супероксиддисмутазу, каталазу), так и уникальные альтернативные - супероксидредуктазу и негемовые НАДН-зависимые $\mathrm{H}_{2} \mathrm{O}_{2}$ пероксидазы (нигеритрин, рубреритрины), активность которых подвержена сложной регуляции и зависит от типа, продолжительности и дозы окислительных стрессов. Для поглощения и 


\section{МАТЕРИАЛЫ КОНФЕРЕНЦИИ}

восстановления кислорода в качестве одного из способов антиокислительной защиты служат цитоплазматические, периплазматические и мембранные электрон-транспортные цепи с участием гидрогеназы, цитохром с оксидазы, $b d$ хинолоксидазы [4].

СРБ активно участвуют в образовании сложных биопленок и являются одними из наиболее коррозионно-активных микроорганизмов (преимущественно за счет катодной деполяризации, обусловленной потреблением водорода с поверхности черных металлов с участием периплазматических гидрогеназных комплексов и связыванием ионов железа в сульфиды или гидроксиды).

С использованием СРБ разрабатывают высокоэффективные методы биоремедиации окружающей среды от токсичных тяжелых металлов, металлоидов и радионуклидов, поскольку в ходе жизнедеятельности СРБ образуются малорастворимые и нетоксичные сульфиды этих химических элементов. Элиминация тяжелых металлов осуществляется клетками СРБ как ферментативным путем (при помощи металл-редуктазных активностей преимущественно широкого спектра действия), так и путем осаждения нерастворимых соединений металлов с сульфидом, образующимся в процессе сульфатредукции [5].

Таким образом, разнообразные в филогенетическом и метаболическом плане строго анаэробные сульфатредуцирующие микроорганизмы играют важнейшую роль как в глобальных природных биогеохимических циклах серы и углерода, в особенности, в морских экосистемах, так и оказывают существенное влияние на антропогенные экосистемы (как негативное, являясь источником деструктивных биокоррозионных процессов, так и позитивное, эффективно участвуя в биоремедиации сточных и шахтных вод от токсичных тяжелых металлов и радионуклидов).

\section{СПИСОК ЛИТЕРАТУРЫ}

1. A psychrophilic sulfate-reducing bacterium from the Black Sea aerobic water / E. E. Zakharova, V. A. Korneeva, A. L. Bryukhanov, N. V. Pimenov // Microbiology. - 2012. - Vol. 81, № 6. - P. 752-754.

2. Investigation of the sulfate-reducing bacterial community in the aerobic water and chemocline zone of the Black Sea by the FISH technique / A. L. Bryukhanov, V. A. Korneeva, T. A. Kanapatskii [et al.] // Microbiology. - 2011. - Vol. 80, № 1. - P. 108-116.

3. Phylogenetic diversity of the sulfur cycle bacteria in the bottom sediments of the Chersonesus Bay / A. L. Bryukhanov, M. A. Vlasova, T. V. Malakhova [et al.] // Microbiology. - 2018. Vol. 87, № 3. - P. 372-381.

4. Response of Desulfovibrio vulgaris Hildenborough to hydrogen peroxide: enzymatic and transcriptional analyses / A. L. Brioukhanov, M. C. Durand, A. Dolla, C. Aubert // FEMS Microbiol. Lett. - 2010. - Vol. 310, № 2. - P. 175-181.

5. Reduction of technetium by Desulfovibrio desulfuricans: biocatalyst characterization and use in a flowthrough bioreactor / J. R. Lloyd, J. Ridley, T. Khizniak, N. N. Lyalikova // Applied and Environmental Microbiology. - 1999. - Vol. 65, № 6. P. 2691-2696.

6. Sulfate-reducing bacterial communities in the water column of the Gdansk Deep (Baltic Sea) / V. A. Korneeva, N. V. Pimenov, A. V. Krek [et al.] // Microbiology. -2015. - Vol. 84, №2. -P. 297-306. 


\section{Information about the Authors}

Andrey L. Brukhanov, PhD in biology, Senior researcher, Associate-professor, Department of Microbiology, Lomonosov Moscow State University, Leninskiye Gory, 1, Bd. 12, 119234 Moscow, Russian Federation, brjuchanov@mail.ru.

Nicolay V. Pimenov, Dr. Sci. (Biology), professor, Head of Laboratory, Laboratory of Relict Microbial Communities, Winogradsky Institute of Microbiology, Research Center of Biotechnology RAS, 60th Anniversary of October Av., 7, Bd. 2, 117312 Moscow, Russian Federation, npimenov@mail.ru.

Tatyana V. Khizniak, Dr. Sci. (Biology), Head of Laboratory, Laboratory of Ecology and Geochemical Activity of Microorganisms, Winogradsky Institute of Microbiology, Research Center of Biotechnology RAS, 60th Anniversary of October Av., 7, Bd. 2, 117312 Moscow, Russian Federation, tanya_khijniak@mail.ru.

\section{Информация об авторах}

Андрей Леонидович Брюханов, старший научный сотрудник, кандидат биологических наук, доцент кафедры микробиологии, Московский государственный университет им. М.В. Ломоносова, Ленинские горы, 1, стр. 12, 119234,г. Москва, Российская Федерация, brjuchanov@mail.ru.

Николай Викторович Пименов, заведующий лабораторией реликтовых микробных сообществ, Институт микробиологии имени С.Н. Виноградского ФИЦ «Фундаментальные основы биотехнологии» РАН, просп. 60-летия Октября, 7, к. 2, 117312 г. Москва, Российская Федерация, npimenov@mail.ru.

Татьяна Владимировна Хижняк, заведующая лабораторией экологии и геохимической деятельности, Институт микробиологии имени С.Н. Виноградского ФИЦ «Фундаментальные основы биотехнологии» РАН, просп. 60-летия Октября, 7, к. 2, 117312 г. Москва, Российская Федерация, tanya_khijniak@mail.ru. 